Review

\title{
Recent Developments in R.F. Magnetron Sputtered Thin Films for pH Sensing Applications-An Overview
}

\section{K. Maurya *, A. Sardarinejad and K. Alameh}

Electron Science Research Institute, Edith Cowan University, Joondalup, WA 6027, Australia;

E-Mails: sardarinejad@gmail.com (A.S.); k.alameh@ecu.edu.au (K.A.)

* Author to whom correspondence should be addressed; E-Mail: d.maurya@ecu.edu.au;

Tel.: +61-863-042-868; Fax: +61-863-042-908.

External Editor: Joaquim Carneiro

Received: 30 September 2014; in revised form: 21 November 2014 / Accepted: 24 November 2014 / Published: 1 December 2014

\begin{abstract}
H}$ sensors are widely used in chemical and biological applications. Metal oxides-based $\mathrm{pH}$ sensors have many attractive features including insolubility, stability, mechanical strength, electrocatalyst and manufacturing technology. Various metal oxide thin films prepared by radio frequency (R.F.) magnetron sputtering have attractive features, including high $\mathrm{pH}$ sensitivity, fast response, high resolution, good stability and reversibility as well as potential for measuring $\mathrm{pH}$ under conditions that are not favourable for the commonly used glass electrodes-based $\mathrm{pH}$ sensors. In addition, thin film $\mathrm{pH}$ sensors prepared by R.F. magnetron sputtering offer many advantages, such as ease of packaging, low cost through the use of standard microfabrication processes, miniaturisation, capability of measuring $\mathrm{pH}$ at high temperatures, ruggedness and disposability. In this paper, recent development of R.F. magnetron sputtered thin films for $\mathrm{pH}$ sensing applications are reviewed.
\end{abstract}

Keywords: R.F. magnetron sputtering; $\mathrm{pH}$ sensor; thin film; metal-oxides

\section{Introduction}

Nearly all processes involving water require accurate $\mathrm{pH}$ monitoring. Most living things rely on a proper $\mathrm{pH}$ level to sustain life. All human beings and animals rely on internal mechanisms to maintain 
the $\mathrm{pH}$ level of their blood, which must be between 7.35 and 7.45. Exceeding this range could prove fatal. Additionally, dysregulated $\mathrm{pH}$ in human tumours has been shown to be correlated with tumour progression and malignancy [1]. Optimal soil $\mathrm{pH}$ provides best growth condition and high crop yields for corn, wheat and other plants as well as food products. Appropriate $\mathrm{pH}$ control retains milk from turning sour, prevents shampoo from hurting our eyes and makes strawberry jelly gel. The $\mathrm{pH}$ of wastewater leaving manufacturing plants, purification plants as well as potable water from municipal drinking water plants, must be within a specific $\mathrm{pH}$ range that is set forth by regulatory agencies. Other pH applications include neutralization of effluent in steel, pulp and paper, chemical, pharmaceutical manufacturing, cyanide destruction, odour scrubbers, reverse osmosis, pharmaceutical manufacturing, chemical and petrochemical manufacturing. Simply, $\mathrm{pH}$ is an integral part of our everyday life [2-4].

The well-known glass electrode is the most commonly used $\mathrm{pH}$ sensor because of desirable characteristics, such as good sensitivity, stability, and long lifetime [5,6]. However, traditional glass electrodes have many disadvantages, such as high cost, mechanical fragility, difficult to miniaturize, need for wet storage, large size and limited shape. To overcome these drawbacks and further expand the application fields, alternative $\mathrm{pH}$ sensor structures based on ion-sensitive field effect transistor (ISFET) [7-9], solid state [10,11], hydrogel [12,13], and microelectrode [14,15], have been reported.

Among different materials, metal oxides, in particular, offer many advantages in terms of $\mathrm{pH}$ sensing including insolubility, stability, mechanical strength, electrocatalyst and manufacturing technology. In recent years, a number of metal oxides based $\mathrm{pH}$ sensors have been developed incorporating $\mathrm{IrO}_{2}$ [16-19], $\mathrm{RuO}_{2}$ [20-24], $\mathrm{PtO}_{2}$ [25], $\mathrm{SnO}_{2}$ [25], $\mathrm{TaO}_{2}$ [25], $\mathrm{TiO}_{2}$ [25,26] and $\mathrm{Ta}_{2} \mathrm{O}_{5}$ [27,28]. pH sensors have been developed using a variety of deposition techniques including magnetron sputtering [20-22], sol-gel [17,29], screen-printing [24,30] and plasma enhanced chemical vapour deposition (PECVD) [31,32] and electroplating [33-35]. Among the different thin film deposition techniques, magnetron sputtering has become the process of choice for the deposition of a wide range of materials. Magnetron sputtering is extensively used in the semiconductor industry for the deposition of various materials significant for integrated circuit fabrication. Thin film sensors and photovoltaic thin films are just some of the various applications of this method. In particular, owing to its compatibility with conventional microfabrication processes, magnetron sputtering technique is advantageous in terms of high-throughput production and fabrication of high density, high quality thin films. Recently, various materials including $\mathrm{RuO}_{x}, \mathrm{RuN}$, $\mathrm{SnO}_{2}$, a-WO$, \mathrm{AlN}, \mathrm{TiO}_{2}, \mathrm{WO}_{3}-\mathrm{IrO}_{2}$, deposited using R.F. magnetron sputtering, have demonstrated excellent capabilities for $\mathrm{pH}$ sensing applications.

In this paper, we review the recent developments in magnetron sputtered thin films for $\mathrm{pH}$ sensing applications with particular emphasis on the $\mathrm{pH}$ sensitivity, response time, drift rate, stability as well as potential for measuring $\mathrm{pH}$ under conditions that are not favourable for the commonly used glass electrodes-based $\mathrm{pH}$ sensors.

\section{R.F. Magnetron Sputtering}

In a basic sputtering process, a target (or source) material, to be deposited onto a substrate, is bombarded by energetic ions, typically inert gas ions, such as Argon $\left(\mathrm{Ar}^{+}\right)$. The forceful collision of these inert gas ions onto the target causes the removal (known as sputtering) of target atoms, which condense on the substrate as a thin film of stoichiometry similar to that of the target material. Though, 
the basic idea of operation is apparently simple, the actual mechanisms involved in sputtering are quite complex. Nonetheless, the process is limited by low deposition rates, high substrate heating and low ionization efficiencies. These limitations have been overcome by the development of magnetron sputtering system.

Magnetron sputtering is now considered as the most effective process for the deposition of a wide range of thin film materials [36-40]. The main driving force behind this development has been the increasing demand for high quality functional thin films in many diverse market sectors. In many cases, magnetron sputtered films now outperform films deposited by other physical vapour deposition processes, and can offer the same functionality as much thicker films produced by other surface coating techniques. Magnetron sputtering systems generate a strong magnetic field near the target area, which causes the travelling electrons to spiral along magnetic flux lines near the target. This arrangement confines the plasma near the target area without causing the damage to the thin films being formed on the substrate, and maintains the stoichiometry and thickness uniformity of the deposited thin film. Moreover, in an R.F. magnetron sputtering systems, the generated electrons travel a longer distance, hence increasing the probability of further ionizing the inert gas atoms $\left(\mathrm{Ar}^{+}\right)$and generating stable high-density plasma that improves the sputtering process efficiency. Figure 1 illustrates the basic components of an R.F. magnetron sputtering system. Briefly, ionised Ar atoms bombard a sputtering target, thus releasing the molecules/atoms that form thin layers on a substrate.

Figure 1. Schematic diagram illustrating the basic components of a magnetron sputtering system.

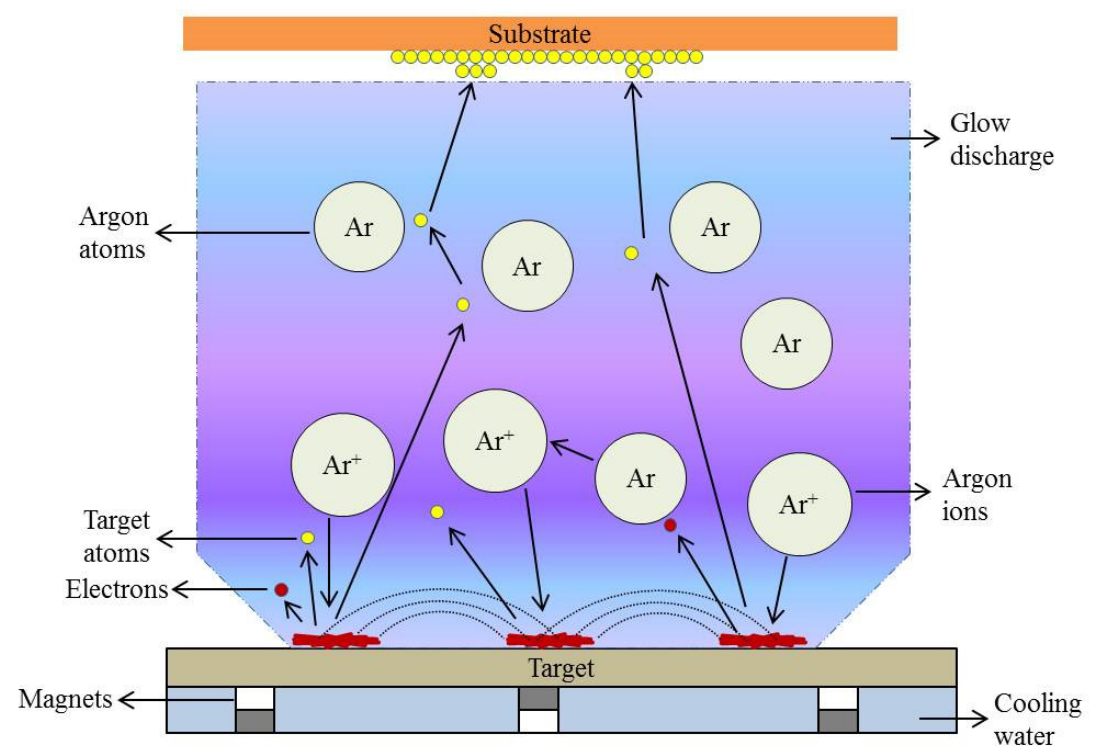

R.F. magnetron sputtering offers additional advantages, including the use of non-conductive targets, charge-up effects and reduced arching due to the use of alternating electric field (R.F. frequency). It is important to note that R.F. magnetron sputtering is especially advantageous in the deposition of thin films using non-conductive target materials. This is at the cost of R.F. power supplies and an impedance matching network between the R.F. generator and the sputtering target. It should also be noticed that without the use of a magnetron, the non-conducting materials may have more difficulty forming into a thin film as they become positively charged. Reactive sputtering can also be used, whereby the deposited film is formed by chemical reaction between the target material and the gas introduced into the vacuum 
chamber. Oxides and nitrides are examples of thin films developed through reactive sputtering, where the compositions of these films can be controlled by adjusting the relative pressures of the inert and reactive gases.

\section{3. pH Sensing Mechanism}

pH measurements have conventionally relied on either optical [41-45] or electrochemical techniques [46-50]. Optical methods offer high sensitivity and non-invasiveness, however, they often require the use of dyes, which can change their optical properties due to interactions with specific analytes. In addition, quantitatively precise optical measurements are typically not straightforward due to the drift of optoelectronic components, such as light source, detector and dye concentration variations. Therefore, it is often necessary to also utilize reference dyes in optical $\mathrm{pH}$ measurement methods. On the other hand, electrochemical methods are typically straightforward and inherently quantitative, and require simpler operation and setups. Electrochemical methods, however, have downsides, such as long-term instability and vulnerability to electrode fouling, but nevertheless, they are the most commonly used methods for $\mathrm{pH}$ detection, whereby the potential (potentiometric) [20,21,51-56], current (amperometric) [57-63], or charge in an electrochemical cell serve as the analytical signals. Indeed, the glass electrode is currently the most commonly used electrochemical sensor for potentiometric $\mathrm{pH}$ measurements.

Potentiometry is the most preferred technique for monitoring the $\mathrm{pH}$ value of aqueous solutions in process control and continuous in-line measurements. In this method, the potential difference between a sensing electrode and a reference electrode immersed in the test solutions is measured. The reference electrode provides a stable constant reference potential while the ion selective electrode (sensing electrode) responds to the change of the hydrogen ion $\left(\mathrm{H}^{+}\right)$concentration in the solution. Potentiometry-based $\mathrm{pH}$ sensors developed using R.F. magnetron sputtering mainly consist a metal-oxide or metal-nitride sensing electrode and a silver/silver chloride $(\mathrm{Ag} / \mathrm{AgCl})$ reference electrode. The $\mathrm{Ag} / \mathrm{AgCl}$ reference electrode either consists of a silver-chloride-coated silver wire immersed in an electrolyte solution or screen-printed using $\mathrm{Ag} / \mathrm{AgCl}$ paste. The equilibrium reaction governing the $\mathrm{Ag} / \mathrm{AgCl}$ electrode potential response is given by $[6,12]$ :

$$
\mathrm{AgCl}_{(\mathrm{s})}+\mathrm{e}^{-} \leftrightarrow \mathrm{Ag}_{(\mathrm{s})}+\mathrm{Cl}_{(\mathrm{aq})}^{-}
$$

Therefore the equilibrium potential of the electrode can be expressed by the Nernstian equation:

$$
E=E^{0}+(R T / n F) \ln \left(a_{\mathrm{AgCl}}\right) /\left(a_{\mathrm{AgCl}^{-}}\right)
$$

where $E^{0}$ is the reference electrode potential in Volt, $R$ is the universal gas constant, $T$ is the absolute temperature in Kelvin, $n$ is the number of electrons involved in the reaction, $F$ is the Faraday constant, $a_{x}$ is the activity of species $x\left(\mathrm{AgCl}, \mathrm{Ag}\right.$ or $\left.\mathrm{Cl}^{-}\right)$. The Nernstian equation for a cell is often articulated in terms of base 10 logarithms as follows:

$$
E=E^{0}-0.592 \log \left|\mathrm{Cl}^{-}\right|+0.0592 \log (k)
$$


where $k$ is the ratio of $\mathrm{AgCl}$ to $\mathrm{Ag}$ concentration. Nernstian behaviour is demonstrated by the electrode when the measured electrode potential decreases by $59 \mathrm{mV}$ for every decade change in $\mathrm{Cl}^{-}$concentration at room temperature of $25^{\circ} \mathrm{C}$.

Fog and Buck proposed five possible interpretations for the $\mathrm{pH}$ response mechanism of metal oxides, with the most recognized theory being oxygen intercalation [25]. The following equilibrium reaction represents the oxygen intercalation mechanism:

$$
\mathrm{Mo}_{x}+2 \delta \mathrm{H}^{+}+2 \delta \mathrm{e} \leftrightarrow \mathrm{Mo}_{x-\delta}+\delta \mathrm{H}_{2} \mathrm{O}
$$

where $\mathrm{MO}_{x}$ is a higher metal oxide, $\mathrm{MO}_{x-\delta}$ is a lower metal oxide and $\delta$ is the oxygen intercalation.

The Nernst's mathematical equation predicting the potential between the sensing and reference electrodes versus the $\mathrm{pH}$ value is given by [21]:

$$
E=E^{0}-2.303(R T / F) \mathrm{pH}=E^{0}-0.05916 \mathrm{pH}
$$

The term $2.303(R T / F)$ is called the Nernst slope, which is $59.16 \mathrm{mV} / \mathrm{pH}$ at room temperature $\left(25^{\circ} \mathrm{C}\right)$.

\section{4. pH Sensor Performance}

\subsection{Sensitivity}

The sensitivity of a $\mathrm{pH}$ electrode is determined by the linear slope response of the $\mathrm{pH}$ electrode as defined by the Nernst equation. It is represented in the unit of $\mathrm{mV} / \mathrm{pH}$ [64].

\subsection{Response Time}

The response time is defined as the time at which the $\mathrm{pH}$ concentration in a solution is changed on contact with a $\mathrm{pH}$ sensor and a reference electrode has reached $95 \%$ (or $90 \%$ ) of the final value. The response time is reported as $t 95 \%$ or $t 90 \%$ in seconds or minutes [5,64].

\subsection{Drift Rate}

The potential drift is defined as the difference between the peak potential value and the $90 \%$ value of the saturated potential. The potential drift measured over time is drift rate and generally represented in $\mathrm{mV} / \mathrm{h}[64]$.

\subsection{Hysteresis}

Hysteresis is defined as the difference in the electrochemical potentials measured at same $\mathrm{pH}$ level. The electrochemical potentials at the same $\mathrm{pH}$ level may be different due to various factors, such as different oxidation states and the degree of hydration on the film surfaces, which may establish a new equilibrium of ions every time in the redox reactions at different times of testing [5,64]. In potentiometric measurements, it is represented in $\mathrm{mV}$. 


\subsection{Temperature Coefficient of Sensitivity}

The temperature coefficient of sensitivity (TCS) is an important parameter that is typically used to compensate for temperature variations, and evaluate the effect of temperature on the output voltage of the $\mathrm{pH}$ sensor. The TCS of the $\mathrm{pH}$ sensor is represented in $\mathrm{mV} / \mathrm{pH}^{\circ} \mathrm{C}[65,66]$.

\subsection{Reversibility}

Reversibility is an essential property in $\mathrm{pH}$ measurements for practical applications. To evaluate the reversibility, the $\mathrm{pH}$ sensor potential is measured in different $\mathrm{pH}$ solutions in the acid-to-base direction and vice versa $[5,21]$.

\subsection{Resolution}

The resolution of a $\mathrm{pH}$ sensor is defined as the minimum change in $\mathrm{pH}$ above the noise floor that can be detected by the $\mathrm{pH}$-sensor $[64,67]$.

\section{5. pH Sensing Materials and Applications}

Table 1 shows the summary of $\mathrm{pH}$ sensing materials prepared by R.F. magnetron sputtering in recent years. $\mathrm{pH}$ sensors are generally characterised using the buffer solutions of known $\mathrm{pH}$ values before applying the sensor for real time $\mathrm{pH}$ monitoring. Recently, we have developed $\mathrm{pH}$ sensor consisting R.F. magnetron sputtered ruthenium oxide $\left(\mathrm{RuO}_{2}\right)$ sensing electrode in conjunction with an on-chip integrated $\mathrm{Ag} / \mathrm{AgCl}$ reference electrode. A 99.95\% pure $\mathrm{RuO}_{2}$ sputtering target was used to sputter $50 \mathrm{~nm}, 175 \mathrm{~nm}, 300 \mathrm{~nm}$ and $425 \mathrm{~nm} \mathrm{RuO}_{2}$ thin-films in 90\% $\mathrm{Ar}+10 \% \mathrm{O}_{2}$ environment with R.F. power $100 \mathrm{~W}$ at $1 \mathrm{mTorr}$ process pressure. Potentiometric measurement has been used to test the sensor in buffer solutions of $\mathrm{pH} 4, \mathrm{pH} 7$ and $\mathrm{pH} 10$. Figure 2 shows the schematic representation of potentiometric measurement setup. Briefly, in the experiments, a unity-gain amplifier was developed and used as a buffer amplifier to provide impedance matching, therefore preventing signal loss. An Agilent 34410A high performance digital multimeter was used for real-time potential recording, which has a built-in web interface that makes it easy to setup and transfer readings using only a PC with web browser. Figure 3 shows measured sensor potential versus $\mathrm{pH}$ value for different $\mathrm{RuO}_{2}$ thin-film thicknesses [21]. Furthermore, effect of $\mathrm{RuO}_{2}$ sensing electrode thickness on the performance of $\mathrm{pH}$ sensing was investigated. The thin film $\mathrm{RuO}_{2}$ sensing electrode with thickness ranging from $50 \mathrm{~nm}$ to $425 \mathrm{~nm}$ were prepared using $99.95 \%$ pure $\mathrm{RuO}_{2}$ sputtering target with R.F. power $100 \mathrm{~W}$ in $90 \% \mathrm{Ar}+10 \% \mathrm{O}_{2}$ environment at $1 \mathrm{mTorr}$ process pressure. The highest sensitivity of $68.63 \mathrm{mV} / \mathrm{pH}$ was reported for $\mathrm{RuO}_{2}$ film thickness of $300 \mathrm{~nm}$ when tested in buffer solutions of $\mathrm{pH} 4, \mathrm{pH} 7$ and $\mathrm{pH} 10$.

Figure 4 shows the response time versus the $\mathrm{RuO}_{2}$ thin-film thickness for different $\mathrm{pH}$ test solutions. For $50 \mathrm{~nm}$ thick $\mathrm{RuO}_{2}$ film, the measured response times were $3 \mathrm{~s}, 10 \mathrm{~s}$ and $73.5 \mathrm{~s}$ for pH 4, $\mathrm{pH} 7$ and $\mathrm{pH}$ 10, respectively. For $175 \mathrm{~nm}$ thick $\mathrm{RuO}_{2}$ film, the response times for $\mathrm{pH} 4, \mathrm{pH} 7$ and $\mathrm{pH} 10$ were from $3 \mathrm{~s}, 4 \mathrm{~s}$ and $22.5 \mathrm{~s}$, respectively. On the other hand, when the thickness of the $\mathrm{RuO}_{2}$ film was increased to $300 \mathrm{~nm}$, the response times for $\mathrm{pH} 4, \mathrm{pH} 7$ and $\mathrm{pH} 10$ were $3 \mathrm{~s}, 8 \mathrm{~s}$ and $3 \mathrm{~s}$, respectively. The results in Figure 4 demonstrate that a faster response time can be attained by increasing the $\mathrm{RuO}_{2}$ thin-film thickness up to $300 \mathrm{~nm}$ [21]. The pH sensor stability measured in $\mathrm{pH} \mathrm{4,} \mathrm{pH} 7$ and $\mathrm{pH} 10$ 
solutions is assessed through the measured potential-versus-time curves shown in Figure 5. It is evident from Figure 5 that the sensing film thickness of $300 \mathrm{~nm}$ shows stable potential outputs for all $\mathrm{pH}$ values. The $\mathrm{pH}$ sensor reversibility was also investigated by switching the $\mathrm{pH}$ sequentially in $\mathrm{pH}$ loop (4-7-10-7-4). Figure 6 shows the average measured potentials for different $\mathrm{RuO}_{2}$ thin film thicknesses. The experimental results in Figure 6 demonstrate an excellent reversibility and stable $\mathrm{pH}$ sensor's response for a sensing film thickness of $300 \mathrm{~nm}$.

Table 1. Magnetron sputtered $\mathrm{pH}$ sensing materials and their performances.

\begin{tabular}{|c|c|c|c|c|c|c|c|}
\hline $\begin{array}{c}\text { pH sensing } \\
\text { material }\end{array}$ & $\begin{array}{c}\text { Sputtering } \\
\text { target material }\end{array}$ & $\begin{array}{l}\text { pH test } \\
\text { solution }\end{array}$ & $\begin{array}{c}\text { pH Sensitivity } \\
(\mathrm{mV} / \mathrm{pH})\end{array}$ & $\begin{array}{c}\text { Response } \\
\text { time (s) }\end{array}$ & $\begin{array}{c}\text { Drift rate } \\
(\mathrm{mV} / \mathrm{h})\end{array}$ & $\begin{array}{c}\text { Hysteresis } \\
(\mathrm{mV})\end{array}$ & Ref. \\
\hline $\mathrm{RuO}_{2}$ & $\mathrm{RuO}_{2}$ & $4-10$ & 58.5 & $<3$ & - & - & [20] \\
\hline $\mathrm{RuO}_{2}$ & $\mathrm{Ru}$ & $4-10$ & $49.8-59.1$ & $<1$ & 0.38 & 4.36 & [22] \\
\hline $\mathrm{RuN}-\mathrm{RuO}_{x}$ & $\mathrm{Ru}$ & $1-13$ & $55.52-57.05$ & 30 & - & - & [23] \\
\hline $\mathrm{Ta}_{2} \mathrm{O}_{5}$ & $\mathrm{Ta}$ & $1-10$ & 56.19 & - & - & $\sim 5$ & [28] \\
\hline $\mathrm{SnO}_{2}$ & $\mathrm{SnO}_{2}$ & $2-12$ & 59 & - & - & $7-11$ & [68] \\
\hline $\mathrm{TiO}_{2}: \mathrm{Ru}$ & $\mathrm{TiO}_{2}, \mathrm{Ru}$ & $1-13$ & 55.20 & $<1$ & $1.03-1.16$ & - & [69] \\
\hline $\mathrm{IrO}_{2} \& \mathrm{Ta}_{2} \mathrm{O}_{5}$ & Ir, $\mathrm{Ta}_{2} \mathrm{O}_{5}$ & $2-13$ & $59.44-59.50$ & $<15$ & $<0.1$ & - & [70] \\
\hline AlN & $\mathrm{Al}$ & $4-10$ & 54.5 & - & - & - & [71] \\
\hline $\mathrm{TiO}_{2}$ & $\mathrm{TiO}_{2}$ & $1-13$ & 56.21 & - & - & - & [72] \\
\hline $\mathrm{WO}_{3}-\mathrm{IrO}_{2}$ & $\mathrm{WO}_{3}-\mathrm{Ir}$ & $2-12$ & $0.168 \mu \mathrm{A} / \mathrm{pH}$ & $<7$ & - & - & [73] \\
\hline $\mathrm{RuO}_{x}$ & $\mathrm{Ru}$ & $5.5-11$ & $52-58$ & $<2$ & $1-2$ & - & [74] \\
\hline $\operatorname{GdTi}_{x} \mathrm{O}_{y}$ & $\mathrm{Gd}, \mathrm{Ti}$ & $2-12$ & 64.13 & - & 0.4 & $<1$ & {$[75]$} \\
\hline
\end{tabular}

Figure 2. Schematic representation of potentiometric measurement setup (S.E. - sensing electrode; R.E.—reference electrode).

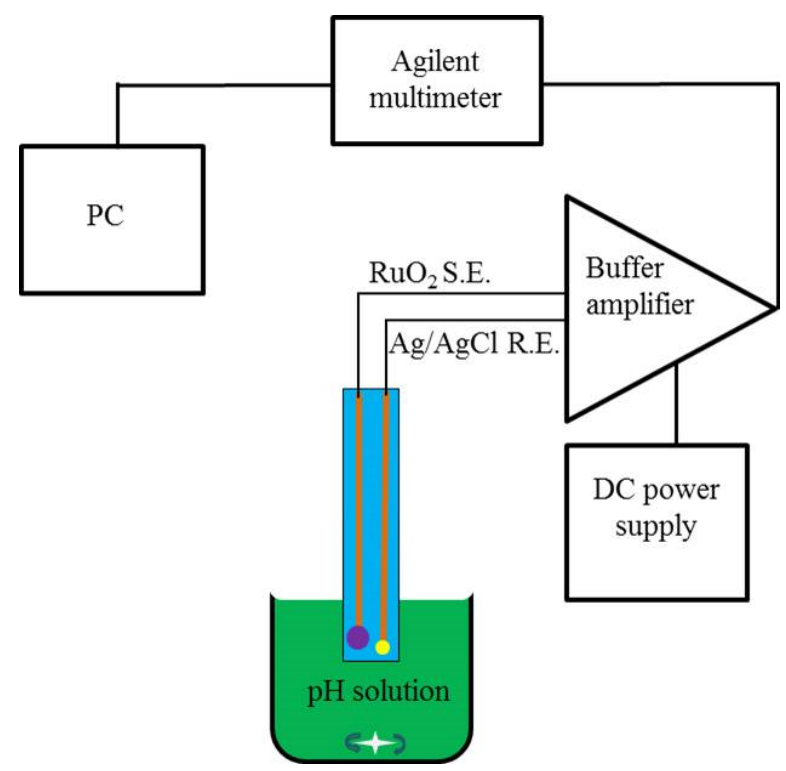


Figure 3. Measured sensor potential versus $\mathrm{pH}$ value for different $\mathrm{RuO}_{2}$ thin-film thicknesses. Reprint with permission from [21]. Copyright 2014 Elsevier.

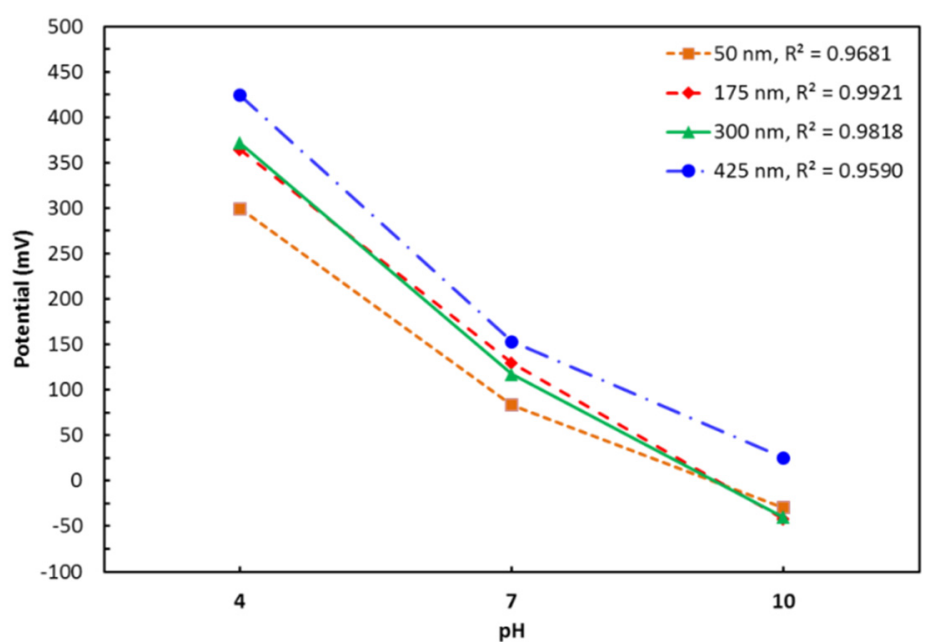

Figure 4. Measured response time versus sensing film thickness for test solutions of different pH values. Reprint with permission from [21]. Copyright 2014 Elsevier.

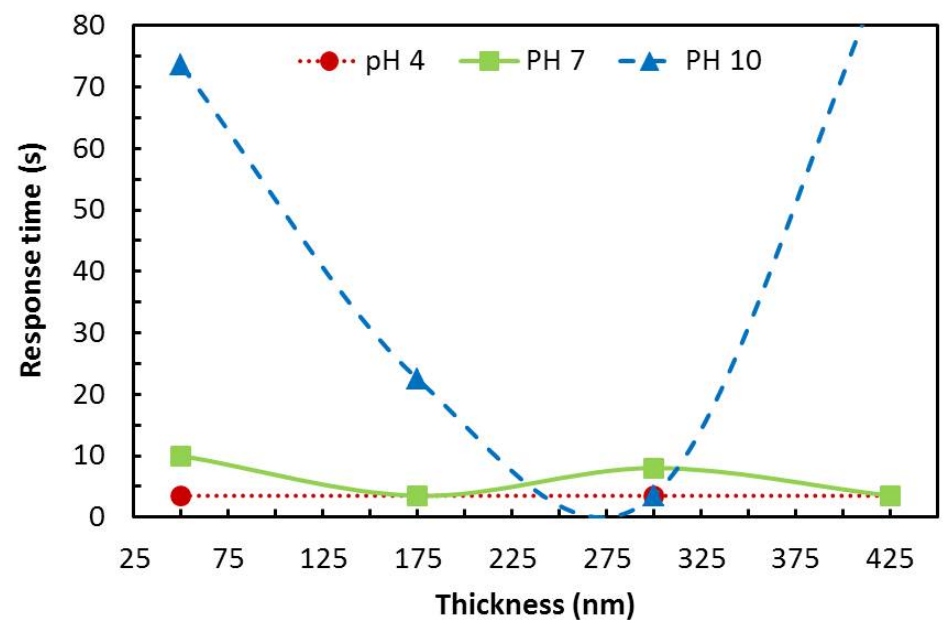

Figure 5. Measured potential in $\mathrm{pH}$ 4-7-10 to demonstrate stability. Reprint with permission from [21]. Copyright 2014 Elsevier.

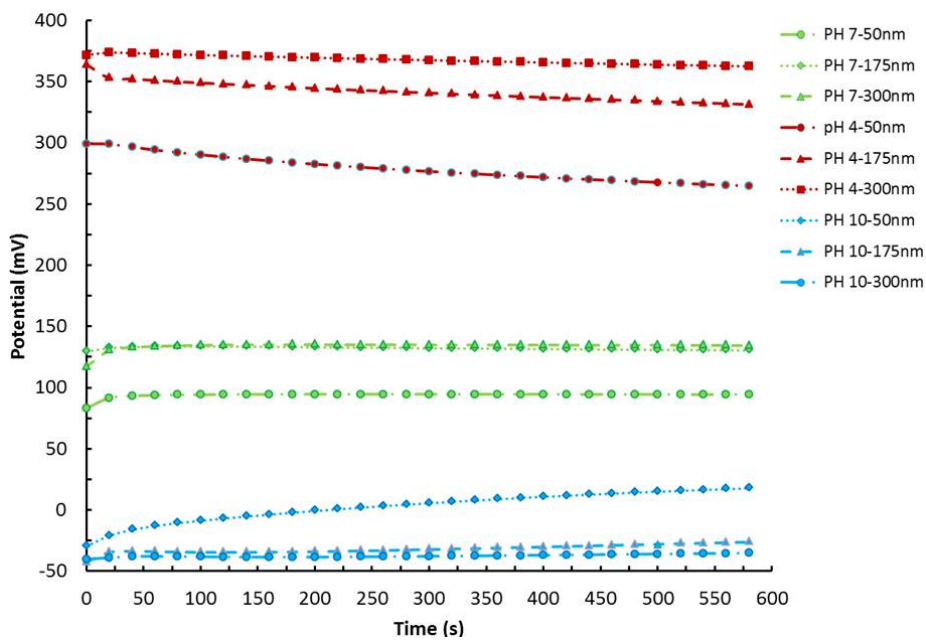


Figure 6. Measured average potential versus time in $\mathrm{pH}$ loop (4-7-10-7-4) for different $\mathrm{RuO}_{2}$ film thickness. Reprint with permission from [21]. Copyright 2014 Elsevier.

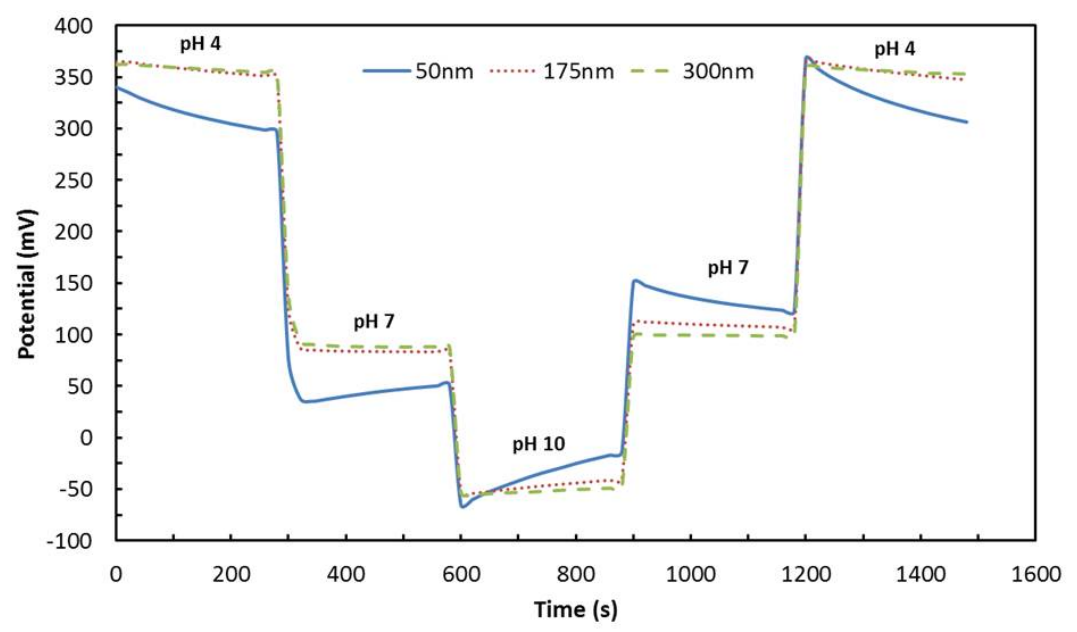

Various materials deposited using magnetron sputtering are listed in Table 1. These materials have been widely studied for $\mathrm{pH}$ sensing application including water quality, engine oil oxidation detection, Coca-Cola, base water, lemon, wine, vinegar, milk, seawater and hard clam (meretrix lusoria) cultivated solutions, glucose concentration, total cholesterol concentration and biosensor applications.

Y. H. Liao et al. [22] have used $\mathrm{RuO}_{2}$ thin film as the sensing layer of hydrogen ion selective electrodes (ISE) for $\mathrm{pH}$ array sensors. The $\mathrm{RuO}_{2} \mathrm{pH}$-sensing membrane was prepared using the R.F. sputtering system at a process pressure of $10 \mathrm{mTorr}$ in $\mathrm{Ar}: \mathrm{O}_{2}=4: 1$ gas ratio at an R.F. power of $100 \mathrm{~W}$ for $1 \mathrm{~h}$. The $\mathrm{pH}$ sensitivity of the $\mathrm{RuO}_{2}$ sensing membrane for the developed ISE devices was about $55.64 \mathrm{mV} / \mathrm{pH}$ and the drift rate was $0.38 \mathrm{mV} / \mathrm{h}$ for a $\mathrm{pH} 7$ buffer solution. The hysteresis widths of the $\mathrm{RuO}_{2}$ ISE device were $4.36 \mathrm{mV}$ and $2.2 \mathrm{mV}$ in $\mathrm{pH}$ 7-4-7-10-7 and $\mathrm{pH}$ 7-10-7-4-7 loop cycles, respectively. J. Chou et al. [23] have investigated reactively sputtered ruthenium oxide $\left(\mathrm{RuO}_{x}\right)$ and ruthenium nitride $(\mathrm{RuN})$ sensing membrane deposited on silicon substrate for $\mathrm{pH}$ sensing applications. The $\mathrm{RuO}_{x}$ film was prepared in an $\mathrm{Ar} / \mathrm{O}_{2}$ process gas ratio of $40 \mathrm{sccm} / 15 \mathrm{sccm}$ at an R.F. power of $100 \mathrm{~W}$ with a $10 \mathrm{mTorr}$ pressure for $60 \mathrm{~min}$. A linear $\mathrm{pH}$ sensitivity of $55.52 \mathrm{mV} / \mathrm{pH}$ was reported for $\mathrm{pH}$ values between 1 and 12 at room temperature. Moreover, in order to increase the sensing range of the $\mathrm{pH}$ sensor, the $\mathrm{RuN}$ was deposited in an $\mathrm{Ar} / \mathrm{O}_{2}$ process gas ratio of $15 \mathrm{sccm} / 30 \mathrm{sccm}$ at $10 \mathrm{mTorr}$ for $1 \mathrm{~h}$ with an R.F. power of $100 \mathrm{~W}$. The RuN membrane exhibited a linear $\mathrm{pH}$ sensitivity of $57.05 \mathrm{mV} / \mathrm{pH}$ over a $\mathrm{pH}$ range of $1-13$ at room temperature. Additionally, $\mathrm{RuO}_{x} / \mathrm{Si}$ sensing membrane tested for the detection of the penicillin $\mathrm{G}$ showed a rapid response time of $35 \mathrm{~s}$ in comparison to $120 \mathrm{~s}$ response time of $\mathrm{SnO}_{2} / \mathrm{ITO}$. M. Chen et al. [28] have developed a $\mathrm{Ta}_{2} \mathrm{O}_{5}$ based capacitive electrolyte-ion sensitive membrane-oxidesemiconductor (EIOS) $\mathrm{pH}$ sensor and investigated its performance by means of electrochemical impedance spectroscopy (EIS) and capacitance-voltage (C-V) measurements. A $60 \mathrm{~nm}$ Ta film was R.F. sputtered onto oxidized silicon substrate in an Ar atmosphere at 3.3 mTorr working pressure with an R.F. power of $300 \mathrm{~W}$ for $5 \mathrm{~min}$. Subsequently, the $\mathrm{Ta}_{2} \mathrm{O}_{5}$ film was obtained by the oxidation of the Ta layer in oxygen atmosphere for about $3 \mathrm{~h}$ at $525{ }^{\circ} \mathrm{C}$, which resulted in a $\mathrm{Ta}_{2} \mathrm{O}_{5}$ film thickness of about $155 \mathrm{~nm}$. Electrochemistry measurements were carried out on an advanced two-electrode electrochemical system, with a conventional $\mathrm{Ag} / \mathrm{AgCl}(3 \mathrm{M} \mathrm{KCl})$ electrode being the reference electrode. A Nernstian 
response of $\sim 56.19 \mathrm{mV} / \mathrm{pH}$ in the $\mathrm{pH}$ range 1 to 10 was attained. The EIS measurement revealed that the space charge capacitance can easily distinguish $\mathrm{pH}$ changes.

C. Tsai et al. [68] have studied the $\mathrm{pH}$ sensing characteristics and hysteresis effect of the R.F. sputtered tin oxide $\left(\mathrm{SnO}_{2}\right)$ electrode. The hysteresis experiments were carried out with short $\mathrm{pH}$ loop (7-4-7-10-7) and long $\mathrm{pH}$ loop (7-2-7-12-6). The hysteresis value was less than $7 \mathrm{mV}$ in short $\mathrm{pH}$ loop and $9 \mathrm{mV}$ for $\mathrm{pH} 7$ in acid side $\left(H_{\mathrm{A}}\right)$ and $11 \mathrm{mV}$ in alkali side $\left(H_{\mathrm{B}}\right)$. The reported $\mathrm{pH}$ sensitivity of the $\mathrm{SnO}_{2}$ was about $59 \mathrm{mV} / \mathrm{pH}$ for $\mathrm{pH}$ range of 2-12. J. C. Chou et al. [69] have carried out long-term monitoring of sea water using solid-state $\mathrm{TiO}_{2}: \mathrm{Ru}$ sensing electrodes for hard clam cultivation. In this study, a co-sputtering system was used to fabricate the $\mathrm{TiO}_{2}$ : $\mathrm{Ru}$ sensing film deposited on a p-type silicon substrate. The co-sputtering parameters were: R.F. power of $100 \mathrm{~W}$, D.C. power of $30 \mathrm{~W}$, process pressure $30 \mathrm{mTorr}$ and $\mathrm{Ar} / \mathrm{O}_{2}$ ratio of $40 \mathrm{sccm} / 2 \mathrm{sccm}$, and a sputtering time of $60 \mathrm{~min}$. The mean sensitivity and linearity of the $\mathrm{TiO}_{2}: \mathrm{Ru}$ sensing electrode were $55.20 \mathrm{mV} / \mathrm{pH}$ and 0.999 , respectively, over a $\mathrm{pH}$ range of 1-13. Particularly, the $\mathrm{TiO}_{2}: \mathrm{Ru}$ sensing electrode was able to measure the $\mathrm{pH}$ levels for two sample solutions of $\mathrm{pH} 8$ and 9, confirming the weak alkali range and suitable meretrix lusoria growth. L. M. Kuo et al. [70] have reported a precise $\mathrm{pH}$ microsensor developed using R.F. sputtering of iridium oxide $\left(\mathrm{IrO}_{2}\right)$ and tantalum pentoxide $\left(\mathrm{Ta}_{2} \mathrm{O}_{5}\right)$ films on Pt-electrode. In their study, an easily implemented surface modification scheme was adopted, based on employing a $\mathrm{Ta}_{2} \mathrm{O}_{5}$ membrane that covers $\mathrm{the} \mathrm{IrO}_{2}$ electrode, making the sensor insensitive to $\mathrm{H}^{+}$ions and hence eliminating redox species interference. The sensitivity of the sensor was in the range of $59.44-59.50 \mathrm{mV} / \mathrm{pH}$ for the $\mathrm{pH}$ range 2-13. Furthermore, the $\mathrm{pH}$ sensor displayed high ion selectivity with respect to $\mathrm{K}^{+}, \mathrm{Na}^{+}$, and $\mathrm{Li}^{+}$with $\log K_{H, M}$ values ( - 12.4) with a working lifetime exceeding one week.

W. Bunjongpru et al. [71] have developed pH-ISFET sensor using CMOS compatible processes. A nanocrystalline-aluminum nitride (AIN) thin film (acted as an ion-sensitive membrane) was prepared by reactive gas-timing R.F. magnetron sputtering without heating the substrate and post annealing. In a conventional reactive gas-timing sputtering system, the feeding gas is on-off controlled periodically in such a way that the deposited $\mathrm{AlO}_{x} \mathrm{~N}_{y}$ film has a quite stable composition of aluminum, nitrogen and oxygen (Al:O:N = 52:18:30\%) all over the entire film area. The deposition parameters used for the preparation of AlN films of various thicknesses $(20,40,80 \mathrm{~nm})$ were $12 \mathrm{sccm}$ Ar and $7 \mathrm{sccm} \mathrm{N} 2$ gas flow, gas-timing (Ar: $\mathrm{N}_{2}=10 \mathrm{~s}: 90 \mathrm{~s}$ ), and an R.F. power of $200 \mathrm{~W}$, without heating the substrate. The $\mathrm{pH}$-sensitivity characteristics showed that the $\mathrm{pH}$ sensitivity increases with increasing the film thickness. The highest $\mathrm{pH}$-sensitivity attained was $54.50 \mathrm{mV} / \mathrm{pH}$, for an AlN layer thickness of $80 \mathrm{~nm}$. J. Chou et al. [72] have investigated the current-voltage characteristics of an ion-sensitive field effect transistor (ISFET) to determine the $\mathrm{pH}$ value at the point of zero charge $\left(\mathrm{pH}_{\mathrm{pzc}}\right)$ of a $\mathrm{pH}$-ISFET device comprising a $25 \mathrm{~nm} \mathrm{TiO} 2$ sensing membrane R.F. sputtered for $120 \mathrm{~min}$ at a pressure of $30 \mathrm{mTorr}$ in $\mathrm{Ar} / \mathrm{O}_{2}=80 \mathrm{sccm} / 20 \mathrm{sccm}$ gas mixture and an R.F. power of $150 \mathrm{~W}$. A pHpzc value of about 6.2 at $25{ }^{\circ} \mathrm{C}$ was reported. pH sensitivities of 51.81, 54.01, 56.21, 58.41, 60.71, 63.01 mV/pH were attained at 5, 15, $25,35,45$ and $55^{\circ} \mathrm{C}$, respectively.

L. M. Kuo et al. [73] have developed a pH-sensor using an R.F. sputtered $\mathrm{WO}_{3} / \mathrm{IrO}_{2}$ diode, which was sealed thoroughly by an $\mathrm{Al}_{2} \mathrm{O}_{3}$ encapsulation layer, and investigated the diode-like current-voltage characteristics of the sensor in response to hydrogen-ions. To develop the $\mathrm{pH}$-sensor structure, an RF-sputtering of the $\mathrm{WO}_{3}$ target (99.99\% pure) was carried out in $\mathrm{Ar}+35 \% \mathrm{O}_{2}$ at a pressure of 45 mTorr and a temperature of $100{ }^{\circ} \mathrm{C}$. Subsequently, an annealing process was carried out in a high temperature 
$\left(350{ }^{\circ} \mathrm{C}\right)$ chamber at a pressure of $15 \mathrm{mT}$ orr for $3.5 \mathrm{~h}$. The $\mathrm{IrO}_{2}$ film was also fabricated by R.F. sputtering using an iridium target (99.95\% pure) at a pressure of 60 mTorr using Ar and 50\% $\mathrm{O}_{2}$ as process gases. Next, the $\mathrm{Al}_{2} \mathrm{O}_{3}$ film was R.F. magnetron sputtered using an $\mathrm{Al}_{2} \mathrm{O}_{3}$ target (99.99\% pure) at a process pressure of 70 mTorr in $\mathrm{Ar}$ and $50 \% \mathrm{O}_{2}$ process gases for $1.5 \mathrm{~h}$. The measured thickness of the $\mathrm{WO}_{3}$, $\mathrm{IrO}_{2}$ and $\mathrm{Al}_{2} \mathrm{O}_{3}$ films were $300 \mathrm{~nm}, 120 \mathrm{~nm}$ and $25 \mathrm{~nm}$, respectively. The solid-state sensor exhibited good stability, repeatability and reversibility in various $\mathrm{pH}$ environments ranging from $\mathrm{pH} 2$ to 12 at room temperature. The $\mathrm{pH}$-sensor sensitivity was $0.168 \mu \mathrm{A} / \mathrm{pH}$ for $\mathrm{pH} 2-12$. It was concluded that the chemically sensitive device would be useful for the construction of durable microsensors for tracing the acidity in environmental and biological applications.

M. Brischwein et al. [74] have demonstrated R.F. sputtered ruthenium oxide sensors for extracellular recording of cell-mediated $\mathrm{pH}$ changes in cell culture media. In this study, ruthenium oxide was directly grown with MCF-7 and L 929 cells and found to be fully biocompatible. The measured $\mathrm{pH}$ sensitivity range was $52-58 \mathrm{mV} / \mathrm{pH}$ and the sensor's response was almost linear between $\mathrm{pH} 5.5-11$. The drift rate of the sensor was typically in the range of $1-2 \mathrm{mV} / \mathrm{h}$. It was also reported that an increase in the thickness of the ruthenium oxide layer increases in response time and decreases in drift rate. In addition, it was observed that the pronounced redox cross-sensitivity of ruthenium oxide is a limiting factor in situations where the concentration of dissolved oxygen is not constant or cannot be directly measured. The observed sensitivity to dissolved oxygen was $\sim 0.2 \mathrm{mV} / \mathrm{hPa}$. Furthermore, ruthenium oxide spots on ceramic sensor chips were used for an exemplary cell based assay with MCF-7 cells, demonstrating an extracellular acidification response to the alkaloid drug cytochalasin $\mathrm{B}$. In comparison with optochemical $\mathrm{pH}$-sensors used for the quantification of extracellular acidification, metal oxides may be directly grown with cells and the active area of sensor spots can be made considerably small. They do not suffer from a gradual decline of performance during operation and they are not affected by interfering fluorescent substances.

J. Her et al. [75] have developed a highly $\mathrm{pH}$ sensitive electrolyte-insulator-semiconductor (EIS) device incorporating $\mathrm{Gd}_{2} \mathrm{O}_{3}$ and $\mathrm{GdTi}_{x} \mathrm{O}_{y}$ sensing films deposited on silicon substrates through reactive R.F. sputtering for biomedical engineering applications. A $40 \mathrm{~nm} \mathrm{Gd} \mathrm{O}_{3} \mathrm{O}_{3}$ film was deposited on a silicon substrate by reactive R.F. sputtering from a gadolinium oxide target in diluted $\mathrm{O}_{2}$ environment $\left(\mathrm{Ar} / \mathrm{O}_{2}=5 \mathrm{sccm} / 2 \mathrm{sccm}\right)$ at a substrate temperature of $27{ }^{\circ} \mathrm{C}$, whereas a $40 \mathrm{~nm} \mathrm{GdTi} x \mathrm{O}_{y}$ film was deposited by reactive R.F. co-sputtering from both gadolinium and titanium targets in the same diluted $\mathrm{O}_{2}$ environment. All samples were annealed in a rapid thermal annealing oven in an $\mathrm{O}_{2}$ environment at selected reaction temperatures in the range of $700-900{ }^{\circ} \mathrm{C}$ for $30 \mathrm{~s}$. Compared with $\mathrm{Gd}_{2} \mathrm{O}_{3}$ sensing membranes, the EIS device featuring $\mathrm{GdTi}_{x} \mathrm{O}_{y}$ sensing membrane annealed at $900{ }^{\circ} \mathrm{C}$ exhibited the highest sensitivity of $64.13 \mathrm{mV} / \mathrm{pH}$ for $\mathrm{pH} 2-12$, a smaller hysteresis voltage of $1 \mathrm{mV}$ for the $\mathrm{pH}$ loop 7-4-7-10-7 and a lower drift rate of $0.4 \mathrm{mV} / \mathrm{h}$ in a $\mathrm{pH} 7$ buffer solution. The high $\mathrm{pH}$ sensitivity was attributed to the high surface roughness of the sensing film. Finally, the detection of glucose in serum was successfully demonstrated using EIS with glucose oxidase-immobilized alginate films. The concentration of serum glucose measured by the $\mathrm{GdTi}_{x} \mathrm{O}_{y}$ EIS biosensor was comparable to that determined by a commercial assay kit. The $\mathrm{GdTi}_{x} \mathrm{O}_{y}$ glucose biosensor can detect glucose with reasonable sensitivity $(8.37 \mathrm{mV} / \mathrm{mM})$ in solutions containing glucose of concentrations in the range $0.5-6 \mathrm{mM}$, making them suitable for general blood glucose monitoring. 


\section{Conclusions}

Recent developments of magnetron sputtered thin films for $\mathrm{pH}$ sensing applications have been reviewed in this paper. Various metal oxide $\mathrm{pH}$-sensing structures prepared by R.F. magnetron sputtering have been used for $\mathrm{pH}$ sensing applications. We have discussed the potential of various metal oxide based $\mathrm{pH}$ sensing electrodes, and highlighted the unique properties of ruthenium oxide and iridium oxide electrodes for $\mathrm{pH}$-sensing applications, such as high sensitivity, good potential stability, wide temperature range, fast response and outstanding corrosion resistance. Furthermore, various applications of magnetron sputtered $\mathrm{pH}$ sensors have been discussed, including fluid quality analysis, glucose and cholesterol concentration monitoring and biosensing.

\section{Acknowledgments}

This research was supported by Edith Cowan University, Australia, and the Department of Industry, Innovation, Science, Research and Tertiary Education, Australian Government.

\section{Author Contributions}

D. K. Maurya drafted and organised this review article. A. Sardarinejad focused on the information about the $\mathrm{pH}$ sensing materials and references. K. Alameh reviewed the manuscript. All authors have read and approved the final manuscript.

\section{Conflicts of Interest}

The authors declare no conflict of interest.

\section{References}

1. Fierro, S.; Seishima, R.; Osamu, N.; Hideyuki, S.; Yasuaki, E. In vivo pH monitoring using boron doped diamond microelectrode and silver needles: Application to stomach disorder diagnosis. Sci. Rep. 2013, 3, doi:10.1038/srep03257.

2. Kohlmann, F.J. What is pH, and How is it Measured? A Technical Handbook for Industry; Hach Company: Loveland, CO, SUA, 2003.

3. Korostynska, O.; Arshak, K.; Gill, E.; Arshak, A. Review on state-of-the-art in polymer based pH sensors. Sensors 2007, 7, 3027-3042.

4. Privett, B.J.; Shin, J.H.; Schoenfisch, M.H. Electrochemical sensors. Anal. Chem. 2010, 82, 4723-4741.

5. Huang, W.D.; Cao, H.; Deb, S.; Chiao, M.; Chiao, J.C. A flexible pH sensor based on the iridium oxide sensing film. Sens. Actuators A Phys. 2011,169, 1-11.

6. Eftekhari, A. pH sensor based on deposited film of lead oxide on aluminum substrate electrode. Sens. Actuators B Chem. 2003, 3, 234-238.

7. Van der Schoot, B.H.; Bergveld, P. ISFET based enzyme sensors. Biosensors 1987, 3, 161-186.

8. Yuqing, M.; Jianguo, G.; Jianrong, C. Ion sensitive field effect transducer-based biosensors. Biotechnol. Adv. 2003, 21, 527-534. 
9. Lee, C.; Kim, S.K.; Kim, M. Ion-sensitive field-effect transistor for biological sensing. Sensors 2009, 9, 7111-7131.

10. Olthuis, W.; Robben, M.A.M.; Bergveld, P.; Bos, M.; Van der Linden, W.E. pH sensor properties of electrochemically grown iridium oxide. Sens. Actuators B Chem. 1990, 2, 247-256.

11. Kinlen, P.J.; Heider, J.E.; Hubbard, D.E. A solid-state $\mathrm{pH}$ sensor based on a nafion-coated iridium oxide indicator electrode and a polymer-based silver chloride reference electrode. Sens. Actuators B Chem. 1994, 1, 13-25.

12. Richter, A.; Paschew, G.; Klatt, S.; Lienig, J.; Arndt, K.; Adler, H.P. Review on hydrogel-based pH sensors and microsensors. Sensors 2008, 1, 561-581.

13. Gerlach, G.; Guenther, M.; Sorber, J.; Suchaneck, G.; Arndt, K.F.; Richter, A. Chemical and pH sensors based on the swelling behavior of hydrogels. Sens. Actuators B Chem. 2005, 111-112, $555-561$.

14. Bezbaruah, A.N.; Zhang, T.C. Fabrication of anodically electrodeposited iridium oxide film $\mathrm{pH}$ microelectrodes for microenvironmental studies. Anal. Chem. 2002, 74, 5726-5733.

15. Ges, I.A.; Ivanov, B.L.; Schaffer, D.K.; Lima, E.A.; Werdich, A.A.; Baudenbacher, F.J. Thin-film $\mathrm{IrO}_{x} \mathrm{pH}$ microelectrode for microfluidic-based microsystems. Biosens. Bioelectron. 2005, 2, 248-256.

16. Kim, T.Y.; Yang, S. Fabrication method and characterization of electrodeposited and heat-treated iridium oxide films for pH sensing. Sens. Actuators B Chem. 2014, 196, 31-38.

17. Nguyen, C.M.; Huang, W.; Rao, S.; Cao, H.; Tata, U.; Chiao, Mu.; Chiao, J. Sol-Gel iridium oxide-based pH sensor array on flexible polyimide substrate. IEEE Sens. J. 2013, 10, 3857-3864.

18. Nguyen, C.M.; Rao, S.; Seo, Y.; Schadt, K.; Hao, Y.; Chiao, J.C. Micro pH sensors based on iridium oxide nanotubes. IEEE Trans. Nanotechnol. 2014, 5, 945-953.

19. Prats-Alfonso, E.; Abad, L.; Casañ-Pastor, N.; Gonzalo-Ruiz, J.; Baldrich, E. Iridium oxide pH sensor for biomedical applications. Case urea-urease in real urine samples. Biosens. Bioelectron. 2013, 1, 163-169.

20. Maurya, D.K.; Sardarinejad, A.; Alameh, K. High-sensitivity pH sensor employing a sub-micron ruthenium oxide thin-film in conjunction with a thick reference electrode. Sens. Actuators A Phys. 2013, 203, 300-303.

21. Sardarinejad, A.; Maurya, D.K.; Alameh, K. The effects of sensing electrode thickness on ruthenium oxide thin-film pH sensor. Sens. Actuators A Phys. 2014, 214, 15-19.

22. Liao, Y.-H.; Chou, J.-C. Preparation and characteristics of ruthenium dioxide for $\mathrm{pH}$ array sensors with real-time measurement system. Sens. Actuators B Chem. 2008, 128, 603-612.

23. Chou, J.; Liu, S.; Chen, S. Sensing characteristics of ruthenium films fabricated by radio frequency sputtering. Jpn. J. Appl. Phys. 2005, 3, 1403-1408.

24. Zhuiykov, S.; O’Brien, D.; Best, M. Water quality assessment by an integrated multi-sensor based on semiconductor $\mathrm{RuO}_{2}$ nanostructures. Meas. Sci. Technol. 2009, 20, doi:10.1088/0957-0233/20/ 9/095201.

25. Fog, A.; Buck, R.P. Electronic semiconducting oxides as pH sensors. Sens. Actuators 1984, 5, 137-146.

26. Chou, J.C.; Liu, C.H.; Chen, C.C. Electrochromic property of sol-gel derived $\mathrm{TiO}_{2}$ thin film for $\mathrm{pH}$ sensor. IFMBE Proc. 2011, 35, 69-72. 
27. Bahari, N.; Zain, A.M.; Abdullah, A.Z.; Sheng, D.B.C.; Othman, M. Study on pH sensing properties of RF magnetron sputtered tantalum pentoxide $\left(\mathrm{Ta}_{2} \mathrm{O}_{5}\right)$ thin film. In Proceedings of 2010 IEEE International Conference on Semiconductor Electronics, Melaka, Malaysia, 28-30 June 2010; pp. $76-78$.

28. Chen, M.; Jin, Y.; Qu, X.; Jin, Q.; Zhao, J. Electrochemical impedance spectroscopy study of $\mathrm{Ta}_{2} \mathrm{O}_{5}$ based EIOS pH sensors in acid environment. Sens. Actuators B Chem. 2000, 71, 73-76.

29. Jeon, D.; Yoo, W.J.; Seo, J.K.; Shin, S.H.; Han, K.; Kim, S.G.; Park, J.; Lee, B. Fiber-optic pH sensor based on Sol-Gel film immobilized with neutral red. Opt. Rev. 2013, 2, 209-213.

30. Glanc-Gostkiewicz, M.; Sophocleous, M.; Atkinson, J.K.; Garcia-Breijo, E. Performance of miniaturized thick-film solid state $\mathrm{pH}$ sensors. Sens. Actuators A Phys. 2013, 202, 2-7.

31. Veeramani, M.S.; Shyam, P.; Ratchagar, N.P.; Chadha, A.; Bhattacharya, E.; Pavan, S. A miniaturized $\mathrm{pH}$ sensor with an embedded counter electrode and a readout circuit. IEEE Sens. J. 2013, 5, 1941-1948.

32. Choi, S.; Park, I.; Hao, Z.; Holman, H.N.; Pisano, A.P. Quantitative studies of long-term stable, top-down fabricated silicon nanowire pH sensors. Appl. Phys. A 2012, 107, 421-428.

33. Huang, X.; Ren, Q.; Yuan, X.; Wen, W.; Chen, W.; Zhan, D. Iridium oxide based coaxial pH ultramicroelectrode. Electrochem. Commun. 2014, 40, 35-37.

34. Grieger, C.; Köster, F. Creation of functional layers for $\mathrm{pH}$ sensors by galvanic deposition of antimony and bismuth. Sci. J. Chem. 2014, 2, 6-10.

35. Lee, Y.; Park, J. Fabrication and characterization of multilayered nanoporous platinum films deposited by electroplating and nonionic surfactant molds. Appl. Surf. Sci. 2013, 277, 100-104.

36. Kelly, P.J.; Arnell, R.D. Magnetron sputtering: A review of recent developments and applications. Vacuum 2000, 56, 159-172.

37. Musil, J.; Baroch, P.; Viček, J.; Nam, K.H.; Han, J.G. Reactive magnetron sputtering of thin films: Present status and trends. Thin Solid Films 2005, 1-2, 208-218.

38. Alam, M.N.; Vasiliev, M.; Kotovb, V.; Alameh, K. Recent developments in magneto-optic garnet-type thin-film materials synthesis. Procedia Eng. 2014, 76, 61-73.

39. Alam, M.N.; Vasiliev, M.; Alameh, K. Bi3Fe5O12:Dy2O3 composite thin film materials for magneto-photonics and magneto-plasmonics. Opt. Mater. Express 2014, 4, 1866-1875.

40. Alam, M.N.; Vasiliev, M.; Alameh, K. Nano-structured magnetic photonic crystals for magneto-optic polarization controllers at the communication-band wavelengths. Opt. Quantum Electron. 2009, 41, 661-669.

41. Michael, W.W.; Aiello, Z.T.; Berliner, A.; Banerjee, P.; Zhou, S. In-situ immobilization of quantum dots in polysaccharide-based nanogels for integration of optical $\mathrm{pH}$-sensing, tumor cell imaging, and drug delivery. Biomaterials 2010, 11, 3023-3031.

42. Zamarreño, C.R.; Hernáez, M.; Villar, I.D.; Matías, I.R.; Arregui, F.J. Optical fiber pH sensor based on lossy-mode resonances by means of thin polymeric coatings. Sens. Actuators B Chem. 2011, 155, 290-297.

43. Wu, W.; Mitra, N.; Yan, E.C.Y.; Zhou, S. Multifunctional hybrid nanogel for integration of optical glucose sensing and self-regulated insulin release at physiological pH. ACS Nano 2010, 8, 4831-4839. 
44. Li, J.; Huang, X.; Xu, W.; Xiao, D.; Zhong, Z. A fiber-optic pH sensor based on relative Fresnel reflection technique and biocompatible coating. Opt. Fiber Technol. 2014, 28-31.

45. Shao, L.; Yin, M.; Tam, H.; Albert, J. Fiber optic pH sensor with self-assembled polymer multilayer nanocoatings. Sensors 2013, 2, 1425-1434.

46. Bakker, E.; Qin, Y. Electrochemical sensors. Anal. Chem. 2006, 78, 3965-3983.

47. Rahman, M.A.; Kumar, P.; Park, D.; Shim, Y. Electrochemical sensors based on organic conjugated polymers. Sensors 2008, 1, 118-141.

48. Wang, F.; Hu, S. Electrochemical sensors based on metal and semiconductor nanoparticles. Microchim. Acta 2009, 1-2, 1-22.

49. Kimmel, D.W.; LeBlanc, G.; Meschievitz, M.E.; Cliffel, D.E. Electrochemical sensors and biosensors. Anal. Chem. 2012, 84, 685-707.

50. Nie, Z.; Nijhuis, C.A.; Gong, J.; Chen, X.; Kumachev, A.; Martinez, A.W.; Narovlyansky, M.; Whitesides, G.M. Electrochemical sensing in paper-based microfluidic devices. Lab Chip 2010, 10, 477-483.

51. Lakard, B.; Segut, O.; Lakard, S.; Herlem, G.; Gharbi, T. Potentiometric miniaturized pH sensors based on polypyrrole films. Sens. Actuators B Chem. 2007, 1, 101-108.

52. Bandodkar, A.J.; Hung, V.W.S.; Jia, W.; Valdés-Ramírez, G.; Windmiller, J.R.; Martinez, A.G.; Ramírez, J.; Chan, G.; Kerman, K.; Wang, J. Tattoo-based potentiometric ion-selective sensors for epidermal pH monitoring. Analyst 2013, 138, 123-128.

53. Guinovart, T.; Valdés-Ramírez, G.; Windmiller, J.R.; Andrade, F.J.; Wang, J. Bandage-based wearable potentiometric sensor for monitoring wound pH. Electroanalysis 2014, 6, 1345-1353.

54. Zuliani, C.; Matzeu, G.; Diamond, D. A potentiometric disposable sensor strip for measuring $\mathrm{pH}$ in saliva. Electrochim. Acta 2014, 132, 292-296.

55. Li, Q.; Li, H.; Zhang, J.; Xu, Z. A novel $\mathrm{pH}$ potentiometric sensor based on electrochemically synthesized polybisphenol a films at an ITO electrode. Sens. Actuators B Chem. 2011, 2, 730-736.

56. Das, At.; Das, An.; Chang, L.B.; Lai, C.; Lin, R.M.; Chu, F.C.; Lin, Y.H.; Chow, L.; Jeng, M.J. GaN thin film based light addressable potentiometric sensor for $\mathrm{pH}$ sensing application. Appl. Phys. Express 2013, 6, doi:10.7567/APEX.6.036601.

57. Lee, H.C.; Zhang, L.F.; Lu, C.H.; Lin, J.L.; Chin, Y.L.; Sun, T.P. Development of anodic titanium oxide nanotubes applied to a $\mathrm{pH}$ sensor with amperometric and potentioimetric methods. Adv. Mater. Res. 2012, 528, 10-13.

58. Shim, J.H.; Kang, M.; Lee, Y.; Lee, C. A nanoporous ruthenium oxide framework for amperometric sensing of glucose and potentiometric sensing of pH. Microchim. Acta 2012, 177, 211-219.

59. Stred'anský, M.; Pizzariello, A.; Stred'anská, S.; Miertuš, S. Amperometric pH-sensing biosensors for urea, penicillin, and oxaloacetate. Anal. Chim. Acta 2000, 1-2, 151-157.

60. Pizzariello, A.; Stredanský, M.; Stredanská, S.; Miertuš, S. Urea biosensor based on amperometric $\mathrm{pH}$-sensing with hematein as a $\mathrm{pH}$-sensitive redox mediator. Talanta 2001, 4, 763-772.

61. Gao, W.; Song, J. Polyaniline film based amperometric $\mathrm{pH}$ sensor using a novel electrochemical measurement system. Electroanalysis 2009, 8, 973-978.

62. Schwarz, M.A.; Hauser, P.C. Recent developments in detection methods for microfabricated analytical devices. Lab Chip 2001, 1, 1-6. 
63. Xu, J.; Bao, N.; Xia, X.; Peng, Y.; Chen, H. Electrochemical detection method for nonelectroactive and electroactive analytes in microchip electrophoresis. Anal. Chem. 2004, 23, 6902-6907.

64. Zhang, X. Nitric oxide (NO) electrochemical sensors. In Electrochemical Sensors, Biosensors and Their Biomedical Applications; Zhang, X., Ju, H., Wang, J., Eds.; Academic Press: Waltham, MA, USA, 2011.

65. Liao, Y.; Chou, J. Fabrication and characterization of a ruthenium nitride membrane for electrochemical pH sensors. Sensors 2009, 9, 2478-2490.

66. Chin, Y.L.; Chou, J.C.; Lei, Z.C.; Sun, T.P.; Chung, W.Y.; Hsiung, S.K. Titanium nitride membrane application to extended gate field effect transistor pH sensor. Jpn. J. Appl. Phys. 2001, 40, 6311-6315.

67. Harsanyi, G. Sensors in Biomedical Applications: Fundamentals, Technology and Applications; CRC Press LCC: Boca Raton, FL, USA, 2000.

68. Tsai, C.; Chou, J.; Sun, T.; Hsiung, S. Study on the sensing characteristics and hysteresis effect of the tin oxide pH electrode. Sens. Actuators B Chem. 2005, 108, 877-882.

69. Chou, J.; Chen, C. Long-term monitor of seawater by using $\mathrm{TiO}_{2}: \mathrm{Ru}$ sensing electrode for hard calm cultivation. Eng. Technol. 2009, 53, 303-307.

70. Kuo, L.; Chou, Y.; Chen, K.; Lu, C.; Chao, S. A precise $\mathrm{pH}$ microsensor using RF-sputtering $\mathrm{IrO}_{2}$ and $\mathrm{Ta}_{2} \mathrm{O}_{5}$ films on Pt-electrode. Sens. Actuators B Chem. 2014, 193, 687-691.

71. Bunjongpru, W.; Porntheeraphat, S.; Trithaveesak, O.; Somwang, N.; Khomdet, P.; Jeamsaksiri, W.; Hruanun, C.; Poyai, A.; Nukeaw, J. The innovative AlN-ISFET based pH sensor. In Proceeds of ECTI-CON 2008. 5th International Conference on Electrical Engineering/Electronics, Computer, Telecommunications and Information Technology, Krabi, Thailand, 14-17 May 2008; pp. 833-836.

72. Chou, J.; Laio, L. Study on $\mathrm{pH}$ at the point of zero charge of $\mathrm{TiO}_{2} \mathrm{pH}$ ion-sensitive field effect transistor made by the sputtering method. Thin Solid Films 2005, 476, 157-161.

73. Kuo, L.; Chen, K.; Chuang, Y.; Chao, S. A flexible pH-sensing structure using $\mathrm{WO}_{3} / \mathrm{IrO}_{2}$ junction with $\mathrm{Al}_{2} \mathrm{O}_{3}$ encapsulation layer. ECS Solid State Lett. 2013, 3, 28-30.

74. Brischwein, M.; Grothe, H.; Weist, J.; Zottmann, M.; Ressler, J.; Wolf, B. Planar ruthenium oxide sensors for cell-on-a-chip metabolic studies. Chem. Anal. (Warsaw) 2009, 54, 1193-1201.

75. Her, J.; Wu, M.; Peng, Y.; Pan, T.; Weng, W.; Pang, S.; Chi, L. High performance GdTi $\mathrm{O}_{y}$ electrolyte-insulator-semiconductor $\mathrm{pH}$ Sensor and biosensor. Int. J. Electrochem. Sci. 2013, 8, 606-620.

(C) 2014 by the authors; licensee MDPI, Basel, Switzerland. This article is an open access article distributed under the terms and conditions of the Creative Commons Attribution license (http://creativecommons.org/licenses/by/4.0/). 